\title{
The effect of irrigation on the yield and quality of maize (Zea mays L.) hybrids
}

\author{
István Csaba Virág ${ }^{1}$ - Attila Miklós Vad ${ }^{2}$ - Erika Tünde Kutasy ${ }^{1}$ \\ ${ }^{1}$ University of Debrecen Faculty of Agricultural and Food Sciences and Environmental Management Institute of Crop Sciences, H-4032 \\ Debrecen Böszörményi str 138 \\ ${ }^{2}$ Institutes for Agricultural Research and Educational Farm, Farm and Regional Research Institute of Debrecen, H-4032 Debrecen \\ Böszörményi str 138 \\ virag.istvan.csaba@agr.unideb.hu
}

\begin{abstract}
SUMMARY
In this study, the effect of water supply on the quality and productivity of different maize hybrids was observed.

Maize production is influenced by many agro-technical factors such as nutrient supply, plant density, environmental factors, water supply and temperature. Good soil quality and adequate technology significantly reduce the unfavourable effect of crop year. The impact of fertilization, crop rotation, irrigation and plant density on maize yield was greatly affected by crop year and crop rotation. The main constituent (69-75\% dry matter concentration) of maize seed is starch, however, its increase can be achieved only to a limited extent, as increasing the starch content will reduce other parameters, especially protein content. Significant nutrient content improvements can be achieved by appropriate hybrid-site connection and the use of adequate technology. Protein content reduction with optimal water supply can be positively influenced by the appropriate nutrient supply for the hybrid.

The experiments were carried out at the Látókép Experimental Site of Crop Production on calcareous chernozem soil. The weather of the examined year, which was partly favorable for maize and partly unfavourable in other respects, was also reflected in the development of maize and yields achieved.

In 2019, we were examining the hybrids of Kamaria (FAO 370), P 9903 (FAO 390), DKC 4351 (FAO 370) and KWS Kamparis (FAO 350 400). Due to the dry soil condition, sowing was delayed, however, the hybrids emerged ideally because rain arrived soon after sowing, which facilitated initial development. Young plants evolved rapidly and dynamically in the case of all hybrids. In terms of heat-demanding bread, the month of May was unfavourable to temperatures below the annual average, but the higher amount rainfall helped the development. However, due to the drier period in early July, 25-25 mm of irrigation water was applied to half of the experimental areas on July 1 and 15.

The aim of our research was to determine the best population density for hybrids under favourable soil conditions (calcareous chernozem soil). In both irrigated and dry conditions, a crop density of 75,000 crops were the most favourable for the Kamaria hybrid. The P9903 hybrid in the case of a crop density of 85 crops proved to be ideal and the DKC4351 had an optimal population density of 95,000.

However, it should be taken into consideration that, in the case of soils with poor water management, the drought sensitivity of the crop stand may increase at a population density of 95,000 .

As a result of irrigation, yield increased and the difference between the examined plant numbers decreased. The yield growth was relatively moderate (341 $\left.\mathrm{kg} \mathrm{ha}^{-1}-1053 \mathrm{~kg} \mathrm{ha}^{-1}\right)$, which makes the economicalness of irrigation doubtful in the given year.
\end{abstract}

Keywords: Corn quality, corn quantity, irrigation effect, hybrid effect, plant density

\section{INTRODUCTION}

In this study the effect of water supply on the quality and productivity of different maize hybrids was observed.

Corn production is influenced by many agrotechnical factors such as nutrient supply, plant density, environmental factors, water supply and temperature (Salifu and Dóka, 2019; Jakab et al., 2005). Ruzsányi and Csajbók (2001) claimed that a good-quality soil and adequate technology significantly reduces the effect of the cropyear. Pepó and Csajbók (2014) (Csajbók et al., 2005) observed the impact of fertilization, crop rotation, irrigation and plant density on the yield of maize. Their results showed that the impact of each agro-technical element on maize yield was greatly affected by crop year and crop rotation. Ványiné et al. (2010) evaluated the effect of sowing date, genotype and crop year on the yield of the maize hybrids and the grain quality parameters (starch, protein and oil content). Based on the examination results, they also found, that crop year has the most significant effect on yield quantity and quality.
Csajbók and Kutasy (2015) note that maize uses water with much less efficiency under favourable water supplying conditions than in dry years. Nagy et al. (2016) in their experiments found that the effect of irrigation on yield in the average of different cropyears is $2.6 \mathrm{t} \mathrm{ha}^{-1}$.

The aim of irrigation is to reduce the risk of cultivation and to achieve yield surpluses. Very important is to be able to give in-field information on when the irrigation is needed to avoid plant damage due to water stress and define the irrigation water needs (Bonfante et al., 2019).

Irrigation also increases nutrient utilization, resulting in a larger photosynthetic surface, while reducing $\mathrm{N}$ loss as $\mathrm{NH}_{3}$ volatility is greatly reduced (Huifang et al., 2019; Csajbók and Kutasy, 2002).

The main constituent $(69-75 \%$ dry matter concentration) of the corn seed is starch. Its increase can be achieved only to a limited extent, as increasing the starch content will reduce other parameters, especially protein content. Significant nutrient content improvements can be achieved by appropriate hybrid site connection and the use of appropriate technology 
(Marton et al., 2008). Protein content in the grain crop, in a broader sense, has a wide range, and its content is not evenly distributed, so any factor that changes the weight of the seed, can influence the proportion of its morphological mass also affect the protein content (Gundel et al., 1981; Hegyi, 2008; Hegyi et al., 2008).

Protein content reduction with optimal water supply can be positively influenced by the appropriate nutrient supply for the hybrid (Győri and Sipos, 2005; Ványiné et al., 2012). In the case of irrigation, despite the decreased protein content of the seed, the protein yield per unit area is higher (Bálint, 1977; Sander et al., 1987).

\section{MATERIALS AND METHODS}

The measurements were carried out at the Farm and Regional Research Institute of Debrecen (FRRID) Látókép Experimental Station of Plant Production on calcareous chernozem soil. The physical property of soil classifies it as a loam. Its $\mathrm{pH}$ is almost neutral, the humus content is medium, the humus layer is about 80 $\mathrm{cm}$ thick. Phosphorus supply is medium, potassium supply is medium to good. The depth of the groundwater is 3 to $5 \mathrm{~m}$, but the water rises to $2 \mathrm{~m}$ in the rainy years.

In the experiment, four hybrids of different growing times (FAO 350-400) were tested with different main water supplies (irrigated, non-irrigated).

Hybrids for test:

Kamária FAO 370

KWS Kamparis FAO 350-400

P 9903 FAO 390

DKC 4351 FAO 370

Sowing date: 18.04.2019

For the irrigated areas, $25 \mathrm{~mm}$ self-propelled irrigation water was applied with "linear" twice:

01/07/2019. $25 \mathrm{~mm}$

$15 / 07 / 2019.25 \mathrm{~mm}$

Harvesting was carried out with a grain harvester on SAMPO plot on 17.10.2019.

The moisture, protein and starch contents of the samples were measured with a Pfeuffer Granolyser NIR Grain Rapid Analyzer.

End-of-variance analysis, correlation calculation, and regression analysis on connectivity sensitivity were performed using the IBM-SPSS statistical program.

Figure 1: Developments of precipitation and temperature 2018-2019

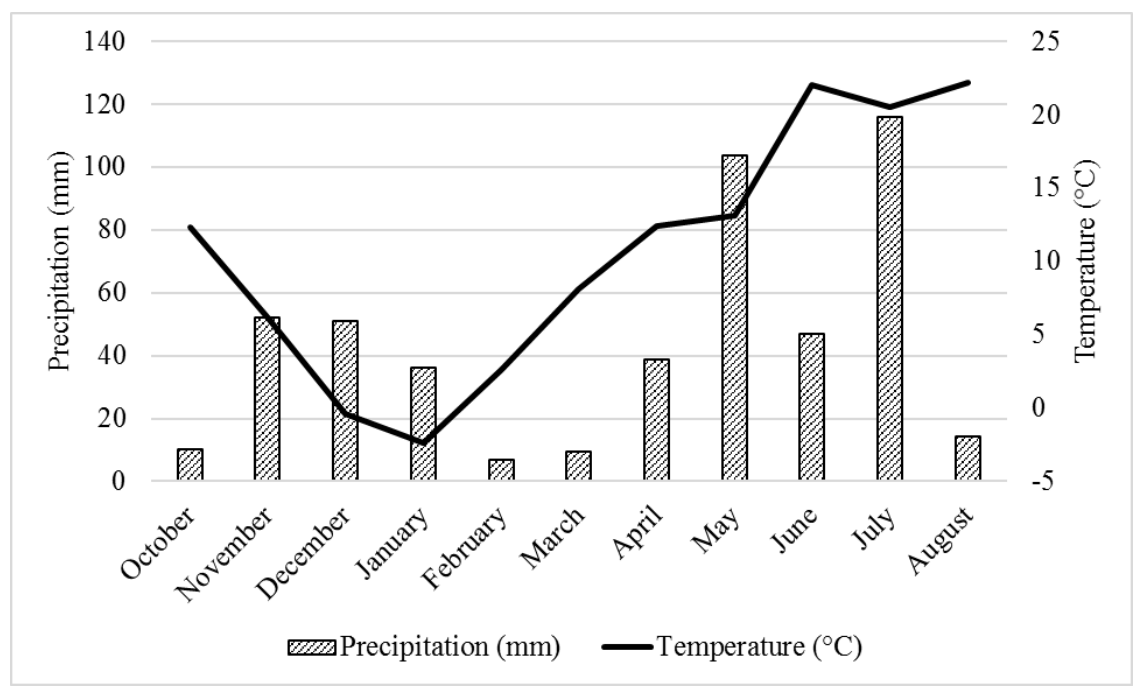

In the autumn 2018, the weather was warmer and drier (Figure 1). In November, the precipitation was remarkably higher than the annual average $(41.6 \mathrm{~mm})$, which was significantly higher $(52 \mathrm{~mm})$ and always above the 30 -years average $\left(4.6^{\circ} \mathrm{C}\right)$ at temperature $(6.2$ $\left.{ }^{\circ} \mathrm{C}\right)$. The winter reflected the long-term average in December and January when it was mild and dry in February. Therefore, the soil is unlikely to get uploaded with water, so spring drought and heat wasn't favorable. Subsequent rainfall in May $(103.7 \mathrm{~mm})$ was well above the multi-year average $(64 \mathrm{~mm})$. However, a lot of rainfall had cooled down, so in one step stopped the rapid development of corn so far. The month of June was quite hot and dry and followed by a rainy July $(115.9 \mathrm{~mm})$. In August, the precipitation was well below the average combined with high temperature, so under the unfavourable conditions, all hybrids reached their biological maturity by the middle of September.

\section{RESULTS AND DISCUSSION}

This year's weather, which was partly favourable for maize and partly unfavourable in other respects, was also reflected in the development of maize and yields achieved. 
In the year 2019, we dealt with the hybrids of Kamaria (FAO 370), P 9903 (FAO 390), DKC 4351 (FAO 370) and Kamparis (FAO 350-400). Due to the dry soil condition, the sowing was delayed, however, the hybrids emerged ideally because the rain arrived soon after sowing, which facilitated initial development. Young plants evolved rapidly and dynamically in all hybrids. In terms of heat-demanding breed, the May was unfavourable due to temperatures below the annual average, but higher rainfall helped the development. However, due to the drier period in early July, 25-25 $\mathrm{mm}$ of irrigation water was applied to half of the experimental areas on July 1 and 15 .

Analysing the results obtained in plots without irrigation, the density of 65 thousand was found to be low for all hybrids, however, hybrids reached the maximum yield at different planting numbers.

Figure 2: The average yield of hybrids in non-irrigated parcels (Debrecen, 2019)

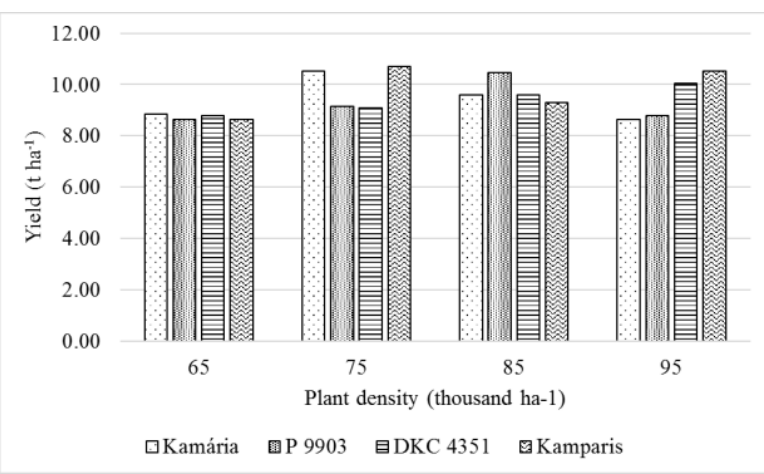

The DKC4351 hybrid was able to increase its yield even at 95 thousand. The stock density of 75 thousand proved to be optimal for the Kamaria hybrid, further increasing the number of plants resulted in crop depression. In the case of P9903, the yield increased to 85 thousand, but it was no longer favourable at the highest stocking density.

Figure 3: Average yield of hybrids in irrigated parcels (Debrecen, 2019)

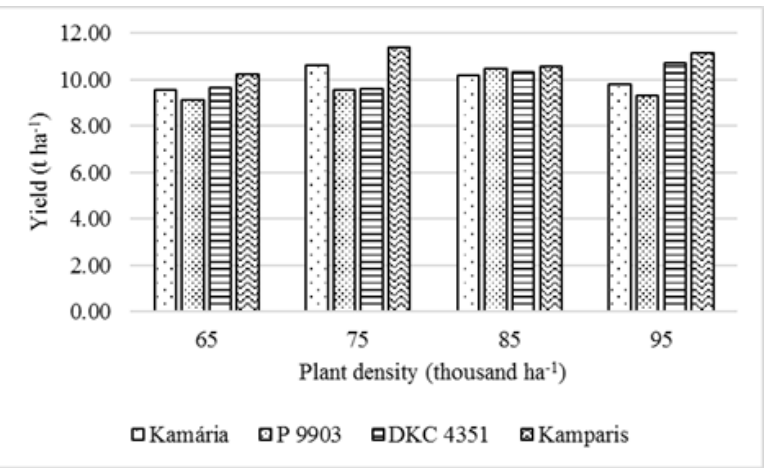

There was no significant yield difference between the Kamaria and DKC4351 hybrids at 65 and 85 thousand plant density.

The relationship between yield and stock density was not clear in the case of the Kamparis hybrid, as the hybrid yielded almost the same yield above $10 \mathrm{t}$ at 75 and 95 thousand, however, the average yield at 85 thousand was lower (9.30 $\mathrm{t} \mathrm{ha}^{-1}$ ) (Figure 2).

We planned irrigation for the critical period, so we applied irrigation water to the plants at the time of the tassel boom, thus helping to set the grains.

Under irrigated conditions at Kamparis, we found the same interesting relationship between plant number and yield. These results are not clear and further research is needed to be carried out (Figure 3).

In irrigated cultivation, all hybrids proved to be most favourable than in non-irrigated plots.

The 75,000 plant population continued to be the best for the Kamaria, the P9903 having the highest yield at 85,000 . In the DKC 4351 we were able to increase the yield to 95,000 , even with a better water supply, although the yield was relatively small (680 $\left.\mathrm{kg} \mathrm{ha}^{-1}\right)$.

Figure 4: The yield of maize hybrids at different water supply (Debrecen, 2019)

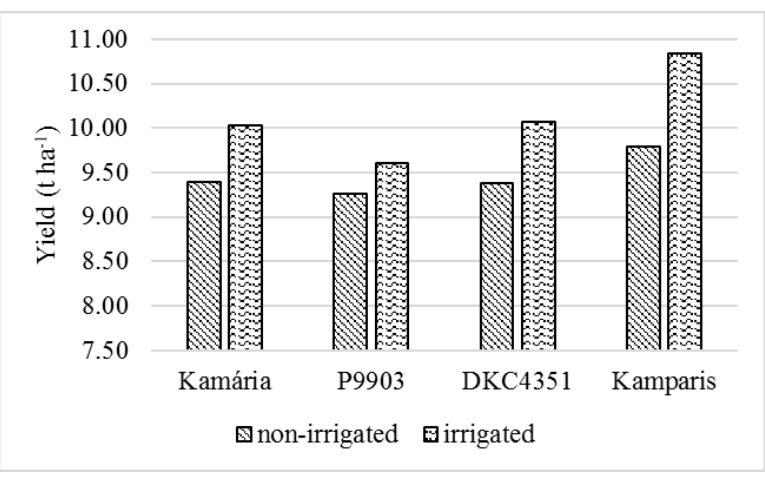

Figure 4 shows the average yield of the nonirrigated and irrigated parcels in case of the different genotypes. The yield of all examined hybrids was higher at better water supply, which clearly indicates that we can find positive connection between the yield and the amount of water. The yield increasing effect of irrigation was different at the genotypes. Irrigation reaction of P9903 was only moderated (341 kg ha-1), while the Kamparis hybrid's yield increasing was larger than the other tested hybrids $\left(1053 \mathrm{~kg} \mathrm{ha}^{-1}\right)$. The Kamparis performed exceptionally well in the examined year in irrigated and non-irrigated plots as well.

Although yield is important, quality is also a significant factor in successful crop production. The starch and protein content of the hybrids were measured in all parcels. P9903 and DKC4351 hybrids had the most favourable protein content. The Hungarian standard has fixed the minimum crude protein content of the fodder maize at $7.6 \mathrm{w} / \mathrm{w} \%$. In our experiment we 
found that the protein content of Kamaria hybrid was lower than that level in irrigated and non-irrigated conditions as well. In irrigated plots in case of all hybrids the decrease of protein content was observed, however, it was not confirmed statistically (Figure 5).

Figure: 5: Protein content of maize hybrids (Debrecen, 2019)

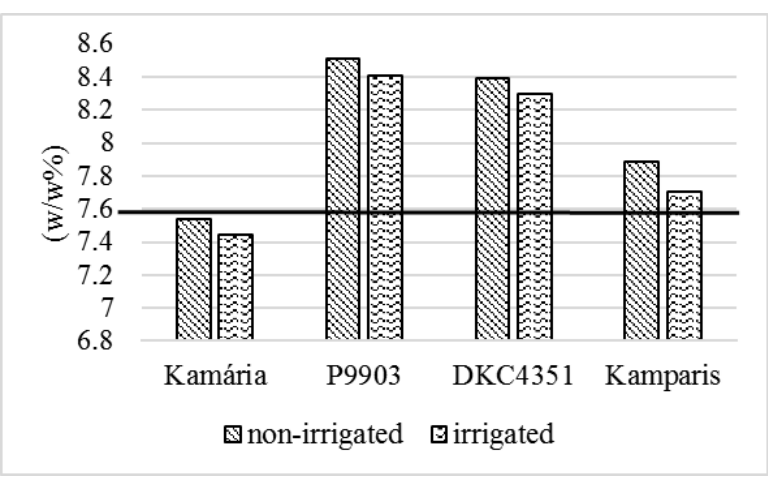

Higher protein content of hybrid P9903 and DKC4351 is associated with lower starch content (Figure 6). The starch content of Kamaria and Kamparis was more favourable than that of the other hybrids examined and increased more due to irrigation. However, the increase is not significant.
Figure 6: Starch content of maize hybrids (Debrecen, 2019)

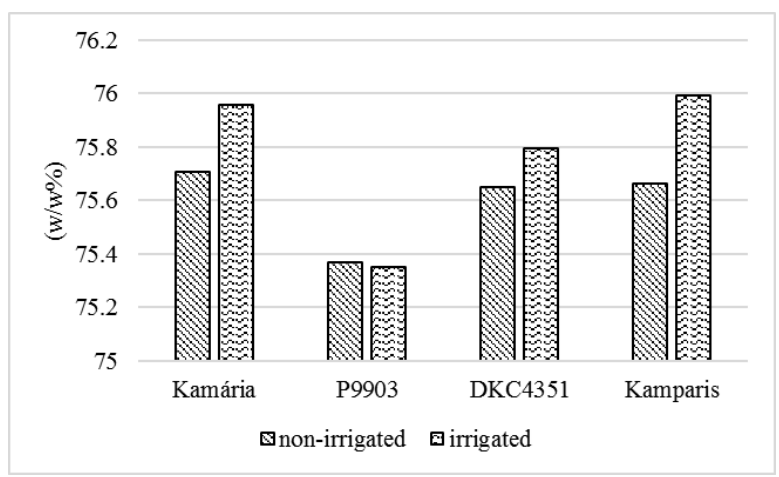

Among the quality parameters, protein and starch content were found to be associated with lower protein content and higher starch content in irrigation with all four genotypes, but these correlations were not significant.

The experimental data were analyzed by Pearson's correlation to reveal the relationships.

On the basis of Pearson's correlation (Table 1), a positive slack correlation was found between irrigation and yield. Moderate negative correlation can be observed between starch and protein. Starch is also positively correlated with the plant density, but this relationship is loose. In other cases, we cannot find statistically confirmed correlation.

Interpretation of results with Pearson correlation (Debrecen 2019)

\begin{tabular}{|c|c|c|c|c|c|c|}
\hline & & Irrigation & Hybrid & Protein & Starch & Yield \\
\hline \multirow[t]{3}{*}{ Irrigation } & Pearson Correlation & 1 & 0.000 & -.098 & .142 & $.368 * *$ \\
\hline & Sig. (2-tailed) & & 1.000 & .271 & .109 & .000 \\
\hline & $\mathrm{N}$ & 128 & 128 & 128 & 128 & 128 \\
\hline \multirow[t]{3}{*}{ Hybrid } & Pearson Correlation & & 1 & .152 & .064 & $.252 * *$ \\
\hline & Sig. (2-tailed) & & & .088 & .476 & .004 \\
\hline & $\mathrm{N}$ & & 128 & 128 & 128 & 128 \\
\hline \multirow[t]{3}{*}{ Protein } & Pearson Correlation & & & 1 & $-.611 * *$ & -.143 \\
\hline & Sig. (2-tailed) & & & & .000 & .106 \\
\hline & $\mathrm{N}$ & & & 128 & 128 & 128 \\
\hline \multirow[t]{3}{*}{ Starch } & Pearson Correlation & & & & 1 & $.206^{*}$ \\
\hline & Sig. (2-tailed) & & & & & .020 \\
\hline & $\mathrm{N}$ & & & & 128 & 128 \\
\hline \multirow[t]{3}{*}{ Yield } & Pearson Correlation & & & & & 1 \\
\hline & Sig. (2-tailed) & & & & & \\
\hline & $\mathrm{N}$ & & & & & 128 \\
\hline
\end{tabular}

**. Correlation is significant at the 0.01 level (2-tailed).

*. Correlation is significant at the 0.05 level (2-tailed).

\section{CONCLUSION}

The aim of the researches was to determine the best stocking density for hybrids under favourable soil conditions (chernozem limestone soil). In both irrigated and dry conditions, 75,000 plant density were the most favourable for the Kamaria hybrid. The P9903 hybrid in the 85 thousand plant density proved to be ideal and the DKC4351 had an optimal stocking density of 95,000 .

However, it should be taken into consideration that in the case of soils with poor water management, the drought sensitivity of the stock may increase at 95,000 population density. 
As a result of irrigation, yield increased and the difference between the examined plant numbers decreased. The yield growth was relatively moderate (341 kg ha-1 $-1053 \mathrm{~kg} \mathrm{ha}^{-1}$ ), which makes the irrigation economical in the given year doubtful, although Nagy et al. (2016) in their experiments found that the effect of irrigation on yield in the average of different cropyears is $2.6 \mathrm{t} \mathrm{ha}^{-1}$.

To sum up, there is a need to repeat this study since one year of experimental data is not enough to make a general conclusion and consequently, it could only be assigned as an initial finding of results.

\section{REFERENCES}

Bálint, A. (1977): A kukorica jelene és jövője. Mezőgazdasági Kiadó. Budapest.

Bonfante, A.-Monaco, E.-Manna, P.-De Mascellis, R.-Basile, A.Buonanno, M.-Cantilena, G.-Esposito, A.-Tedeschi, A.-De Michele, C.-Belfiore, O.-Catapano, I.-Ludeno, G.-Salinas, K.Brook A. (2019): LCIS DSS-An irrigation supporting system for water use efficiency improvement in precision agriculture: A maize case study Agricultural Systems 176.

Csajbók, J.-Kutasy, E. (2015): Changes in water use efficiency and photosynthetic parameters of maise. induced by abiotic stress factors, Növénytermelés 64. supp. 2.

Csajbók, J.-Kutasy, E.-Hunyadi Borbélyné, É.-Lesznyák, M-néFutó, Z.-Jakab, P. (2005): Effects of nutrient supply on the photosynthetis of maize hybrids Cereal Research Communications 33: 1 pp. 169-172.

Csajbók, J.-Kutasy, E. (2002): A tápanyagellátás és a fotoszintetikus aktivitás összefüggései kukorica hibrideknél In: Pepó, P.Jolánkai, M (szerk.) II. Növénytermesztési Tudományos Nap elöadásainak és posztereinek összefoglalói: Integrációs feladatok a hazai növénytermesztésben Budapest, Magyarország. MTA Növénytermesztési Bizottság, (2002) pp. 173-179.

Gundel, J.-Babinszky, L.-Kemenes, M. (1981): A silózással tartósított szemes kukorica takarmányértéke hízó sertések részére. Állattenyésztés és takarmányozás. Budapest. 30: 107115.

Győri, Z.-Sipos, P. (2005): Kukoricahibridek minőségének változása agrotechnikai kísérletben. [In: Nagy J. (szerk.) Kukoricahibridek adaptációs képessége és termésbiztonsága]. Debreceni Egyetem Agrártudományi Centrum. Debrecen. 101-114.

Hegyi, Zs. (2008): Minőség, évjárat és hibridválasztás összefüggései. Az MTA Mezőgazdasági Kutatóintézetének és Kísérleti Gazdaságának Közleményei. 2: 16-18.

Hegyi, Zs.-Pók, I.-Berzy, T.-Pintér, J.-Marton, L. Cs. (2008): Comparison of the grain yield and quality potential of maize hybrids in different FAO maturity groups. Acta Agronomica Hungarica. 56: 161-167.
Huifang, Z.-Hao, Y.-Yulong, Y.-Yingcheng, W.-Gang, H.Qianqian, B.-Zhenling, C.-Qinghua, Y. (2019): Irrigation leads to greater maize yield at higher water productivity and lower environmental costs: a global meta-analysis Agriculture, Ecosystems \& Environment 273. 62-69.

Jakab, P.-Futó, Z.-Csajbók, J. (2005): Analyze of photosynthesis and productivity of maize hybrids in different fertilizer treatments Cereal Research Communications 33:1 pp. 205-207.

Salifu, M.-Dóka, L. F. (2019): Effects of plant density on photosynthetic characteristics and yield of maize under irrigation condition Agrártudományi Közlemények/Acta Agraria Debreceniensis:1 pp. 115-118.

Marton, L. Cs.-Hadi, G.-Pintér, J.-Hegyi, Zs.-Nagy, E.-Spitkó, T.Szöke, Cs. (2008): Kukorica:a jövő növénye. Sokhasznú kukoricahibridek, Az MTA Mezőgazda- sági Kutató intézetének és Kísérleti Gazdaságának Közleményei. 1: 3-6.

Nagy, J.-Rátonyi, T.-Széles, A. (2016): A klímaváltozás okozta növényi stressz mérséklése. Debreceni Szemle 24. 2: 133-141.

Pepó, P.-Csajbók, J. (2014): Agrotechnikai tényezők szerepe a kukorica (Zea Mays L.) termesztésben Növénytermelés 63:2 pp. $45-68$.

Ruzsányi, L.-Csajbók, J. (2001): Termésstabilitás és az évjárat kölcsönhatása a fontosabb szántóföldi növényeinknél Agrártudományi Közlemények/Acta Agraria Debreceniensis 2 pp. 41-46.

Sander, D. H.-Allaway, W. H.-Olson, R. A. (1987): Modification of nutritional quality by environment and production practices [In: Olson, R. A.-Frey, K. J. (eds.) Nutritional quality of cereal grains]. ASA. CSSA. Madison. Wise., USA. 45-82.

Ványiné Széles, A.-Tóth, B.-Nagy, J. (2012): Effect of nitrogen doses on the chlorophyll concentration, yield and protein content of different genotype maize hybrids in Hungary. African Journal of Agricultural Research. 7. 16: 2546-2552.

Ványiné Széles, A.-Megyes, A.-Nagy, J. (2010): Vetésidő és az évjárat hatása a kukoricahibridek terméshozamára és minőségére. Növénytermelés, 59. 4: 63-88. 
